LingTera
Available online at: http://journal.uny.ac.id/index.php/litp
LingTera, 6 (1), 2019, 17-29

\title{
Pengembangan kamus bahasa Jawa digital berbasis android
}

\author{
Nur Hanifah Insani * 1, Mulyana Mulyana ${ }^{2}$ \\ ${ }^{1}$ Program Studi Pendidikan Bahasa Jawa, Universitas Negeri Semarang. \\ Sekaran, Gunung Pati, Sekaran, Kota Semarang, Jawa Tengah 50229, Indonesia \\ ${ }^{2}$ Program Studi Pendidikan Bahasa Jawa, Universitas Negeri Yogyakarta. \\ Jalan Colombo No. 1, Karangmalang, Yogyakarta 55281, Indonesia \\ * Coresponding Author. E-mail: hanifah.insani@yahoo.com \\ Received: 14 April 2019; Revision: 12 June 2019; Accepted: 18 June 2019
}

\begin{abstract}
Abstrak
Penelitian ini bertujuan untuk mengembangkan media pembelajaran bahasa Jawa digital berbasis android serta mengetahui kualitas produk media pembelajaran bahasa Jawa berbasis android. Jenis penelitian ini merupakan penelitian pengembangan (R\&D) yang diadaptasi dari Borg \& Gall dengan model prosedural yang terdiri dari tahap pendahuluan, tahap pengembangan produk, serta tahap evaluasi (ujicoba) produk. Penilaian produk dilakukan oleh ahli media, ahli materi, guru bahasa Jawa, dan peserta didik. Teknik pengumpulan data menggunakan kuesioner kemudian data dianalisis secara deskriptif kuantitatif. Hasil penelitian menunjukkan bahwa produk media pembelajaran kamus bahasa Jawa berbasis android termasuk dalam kategori baik sekali. Demikian juga ahli media, ahli materi, juga guru bahasa Jawa menilai kualitas multimedia pembelajaran bahasa Jawa baik sekali. Para siswa juga sangat setuju dengan adanya mulitmedia kamus bahasa Jawa digital berbasis android. Berdasarkan hasil tersebut, maka produk kamus bahasa Jawa digital berbasis android sangat layak digunakan dalam pembelajaran bahasa Jawa.
\end{abstract}

Kata Kunci: pengembangan media pembelajaran, kamus bahasa Jawa digital berbasis andorid

\section{Developing android-based Javanese digital dictionary}

\begin{abstract}
This research aims to develop android-based Javanese digital dictionary and to reveal the quality of androidbased Javanese digital dictionary. The study is a research and development adapted from Borg and Gall that consist of preliminary studies, product development, and evaluating the product. The product assessment was conducted by a media expert, a material expert, Javanese teachers and the students. The data collecting technique was done by using questionnaires, then it was analysed using descriptice quantitative technique. The results of this research show that the product resulted of developing android-based Javanese digital dictionary falls into the category of very good. From the view of experts in media and material also Javanese teacher rates the quality of the multimedia is very good. The students also very agree with the product has been made. Based on the results, the product of android-based Javanese digital dictionary is very feasible to be used in Javanese learning.
\end{abstract}

Keywords: development, product, android-based Javanese digital dictionary

How to Cite: Insani, N., \& Mulyana, M. (2019). Pengembangan kamus bahasa Jawa digital berbasis android. LingTera, 6(1). doi:https://doi.org/10.21831/lt.v6i1.24435

This is an open access article under the CC-BY-SA license.

\section{PENDAHULUAN}

Saat ini, bahasa Jawa menjadi salah satu mata pelajaran yang dianggap sulit dipelajari oleh siswa (Arafik \& Rumidjan, 2017). Penyebabnya beraneka ragam, seperti pendapat para siswa yang mengatakan bahwa bahasa Jawa itu bahasa yang kuno, tidak modern, tidak gaul, sehingga sudah tidak cocok dengan perkembangan zaman. Selain itu kebanyakan orang tua saat ini sudah agak mengesampingkan pendidikan bahasa ibu kepada anak-anaknya. Bahasa Jawa sebagai bahasa ibu mayoritas penduduk di Jawa sudah tidak lagi diajarkan oleh para orang tua sejak anak masih belia, akibatnya lunturlah kecintaan 


\section{LingTera,6 (1), 2019 - 18}

\section{Nur Hanifah Insani, Mulyana Mulyana}

anak untuk melestarikan bahasa Jawa dalam kehidupan sehari-hari karena tidak sering dipakai untuk berkomunikasi. Dalam pembelajaran bahasa Jawa di sekolah, para siswa juga berpendapat bahwa model pembelajaran serta metode pembelajaran bahasa Jawa oleh para guru masih terlihat konvensional sehingga menghilangkan semangat para peserta didik untuk memperhatikan guru ketika menyampaikan pelajaran di kelas.

Collins \& Halverson (2018, p.129) mengatakan bahwa pada kenyataannya proses pembelajaran di sekolah-sekolah berjalan dengan sangat lambat karena teknologi pembelajaran yang sudah ada belum dapat diterapkan dengan baik di dalam pembelajaran. Kebanyakan guru yang masih menggunakan metode mengajar secara konvensional disebabkan karena masih rendahnya sumber daya manusianya untuk mengaplikasikan teknologi pembelajaran dengan baik dalam proses pembelajaran bahasa Jawa. Pemilihan metode pembelajaran yang cocok dengan karakteristik siswa dengan cara memanfaatkan teknologi pembelajaran yang sudah ada tentu saja akan meningkatkan motivasi siswa untuk belajar bahasa Jawa.

Dari berbagai penyebab yang ada, inti dari permasalahan pembelajaran yang menyebabkan siswa kesulitan mengikuti proses pelaksanaan pembelajaran bahasa Jawa di kelas berhubungan dengan kurangnya pengetahuan siswa tentang penguasaan kosakata bahasa Jawa. Kurangnya pengetahuan siswa mengenai kosakata bahasa Jawa yang menyebabkan para siswa tidak dapat berkomunikasi menggunakan tingkat tutur bahasa Jawa yang baik dengan orang-orang yang lebih tua umurnya. Berdasarkan hasil observasi prasurvei yang dilakukan di SMK Muhammadiyah 2 Salam, Magelang, kebanyakan siswa bisa menggunakan bahasa Jawa dalam berkomunikasi sehari-hari, tetapi penggunaan ragam bahasa serta tingkat tuturnya masih menggunakan ragam bahasa ngoko. Sebagian siswa juga telah berusaha mencoba menggunakan bahasa Jawa ragam krama, tetapi masih sering keliru penggunaannya. Para siswa merasa kesulitan jika harus menggunakan bahasa Jawa ragam krama ketika berbicara dengan orang yang lebih tua. Pada akhirnya mereka menggunakan bahasa campuran antara ragam krama dan ngoko dalam bertutur sehari-hari.

Bahasa Jawa terkenal memiliki tingkat tutur bahasa yang paling banyak. Penggunaannya pun harus disesuaikan dengan lawan tuturnya. Saat ini, tingkat tutur bahasa Jawa sudah semakin sederhana karena dari awal mula terdapat 13 tingkat tutur, sekarang tinggal 2 tingkat tutur, yaitu ragam krama dan ngoko. Tingkat tutur yang semakin sederhana ini tentu tidak akan lagi menyulitkan dan membani siswa dalam mempelajarinya, lebih lagi ketika harus menerapkannya dalam kehidupan sehari-hari. Akan tetapi, mudah tidaknya para siswa menggunakan bahasa Jawa kembali lagi pada kebiasaan sehari-hari para siswa, apakah mereka membiasakan menggunakan bahasa Jawa dalam kehidupan sehari-hari atau tidak. Semakin sering peserta didik mengaplikasikan bahasa Jawa dalam kehidupannya, tentu hal tersebut akan memepengaruhi kelancaran bicaranya saat harus berkomunikasi dengan lawan tuturnya.

Salah satu cara yang dapat dilakukan untuk mengatasi kelemahan siswa atas rendahnya pengetahuan tentang kosakata bahasa Jawa tentunya dengan memperluas pengetahuan kosakatanya. Cara untuk memperluas kosakata bahasa Jawa dapat dilakukan dengan memperbanyak membaca bacaan bahasa Jawa, dengan mencocokkan kata dengan konteks kalimatnya, atau bisa dengan mencari arti kata tersebut dalam kamus bahasa Jawa. Ada berbagai macam jenis kamus yang dapat digunakan untuk memperluas pengetahuan kosakata, seperti kamus sinonim, tesaurus, dan bausastra. Sayangnya, tidak semua siswa memiliki kamus bahasa Jawa. Alasannya beragam dari mulai harga kamus yang mahal, tidak memiliki uang, serta sulit dicari. Oleh karena itu, harus ada suatu media pembelajaran yang dapat digunakan siswa untuk menambah pengetahuan kosakata bahasa Jawa dengan mempersempit kemungkinan-kemungkinan siswa merasa bosan ketika menggunakan media pembelajaran tersebut. Media atau metode pembelajaran yang akan dibuat nantinya harus sesuai dengan perkembangan zaman sehingga para siswa dapat dengan sungguh-sungguh belajar bahasa Jawa. Dengan demikian, pengetahuan para siswa mengenai kosakata bahasa Jawa dapat meningkat lebih banyak dan proses pembelajaran bahasa Jawa pun dapat berjalan dengan lancar.

Menurut Latuheru (1988, p.15) media pembelajaran adalah semua alat bantu yang dapat digunakan dalam proses pembelajaran. Tujuannya untuk menyampaikan pesan serta makna pelajaran tersebut dari sumber pembelajaran (guru atau sumber lainnya) kepada orang yang menerima pembelajaran yakni siswa itu sendiri. Pada umumnya, pengertian media pada pembelajaran di sekolah lebih sering disampaikan sebagai alat grafis, photografis, atau elektronis untuk me- 


\section{LingTera, 6 (1), 2019 - 19}

Nur Hanifah Insani, Mulyana Mulyana

nyerap semua pengetahuan yang berwujud visual atau verbal (Kustandi \& Sutjipto, 2011, p.7).

Media pembelajaran penting sekali kedudukanya dalam proses pembelajaran (Agustien, Umamah, \& Sumarno, 2018). Hasil penelitan dari (Kartikasari, 2016; Yulianti, Herkulana, \& Achmadi, 2018) menunjukkan bahwa ketika guru menggunakan media pembelajaran dalam proses pembelajaran hal itu dapat meningkatkan serta memberikan pengaruh terhadap hasil pembelajaran para siswa. Lebih lagi jika guru dapat menggunakan media pembelajaran dan metode pembelajaran yang tepat bagi siswa (Ramadhani, Koryati, \& Deskoni, 2015). Levie \& Lentz (1982) menjelaskan empat kegunaan media pembelajaran, yaitu fungsi atensi, fungsi afektif, fungsi kognitif, dan fungsi kompensatoris (Annisah, 2017; Irwandani \& Juariyah, 2016).

Masalah kurangnya pengetahuan siswa tentang kosakata bahasa Jawa juga dapat diselesaikan dengan memanfaatkan teknologi modern yang telah ada. Caranya dengan membuat suatu media pembelajaran berbasis teknologi dimana media pembelajaran yang dibuat nantinya juga bisa berkedudukan sebagai suatu sumber pembelajaran. Menurut AECT (Association for Educational Communication and Technology), sumber belajar adalah semua sumber (dapat berupa data, orang atau benda) yang dapat digunakan sebagai sarana belajar siswa (Usman \& Asnawir, 2002, p.1). Sumber belajar termasuk juga semua hal berwujud benda atau jenis lainnya untuk mencapai tujuan pembelajaran yang dapat digunakan oleh guru.

Salah satu sumber belajar yang juga dapat berfungsi sebagai media pembelajaran dan dapat digunakan oleh siswa untuk memperluas ilmu pengetahuannya khusunya mengenai kosakata bahasa Jawa adalah kamus bahasa Jawa. Sejatinya kamus adalah suatu sumber belajar, tetapi ketika kamus dibuat dengan wujud atau tampilan yang lebih baik sehingga siswa dapat memiliki pengalaman yang nyata ketika menggunakannya, maka kamus tersebut dapat berperan ganda sebagai media pembelajaran pula. Pada kenyataannya, kamus-kamus bahasa Jawa yang berbentuk cetak telah cukup banyak dibuat, tetapi kamus tersebut belum mampu menarik keinginan para siswa untuk belajar. Oleh karena itu perlu kiranya diadakan suatu inovasi pembelajaran untuk membuat suatu bentuk media pembelajaran kamus bahasa Jawi yang lebih menarik untuk siswa.

Akhir-akhir ini, para siswa sudah banyak yang mempunyai gadget (mobile devices) seperti handphone, tablet, notebook atau laptop. Harga beraneka ragam peralatan elektronik yang terjangkau oleh masyarakat lah yang menyebabkan semua golongan masyarakat di zaman sekarang ini dapat membeli jenis gadgetyang diinginkan dengan mudah. Saat ini sudah tidak banyak lagi orang yang buta akan peralatan elektronik yang beraneka ragam jenisnya, lebih lagi para generasi muda yang kehidupannya tidak bisa lepas dari belenggu gadget sehari-harinya. Semakin banyak masyarakat yang menggunakan perangkat mobile tentu hal itu akan memperlebar peluang untuk mengembangkan beraneka ragam jenis teknologi mutakhir dalam dunia pendidikan. Perangkat mobile devices yang digunakan dalam proses pembelajaran lalu terkenal dengan sebutan mobile learning (m-learning) (Azmi, Maryono, \& Rosihan, 2016; Silviarista, \& Setyosari, 2018; Georgiev, Georgieva, \& Smrikarov, 2004; Purbasari, Kahfi, \& Yunus, 2013, p.2).

Darmawan (2012, p.15) menjelaskan bahwa m-learning adalah salah satu cara alternatif bahwa proses pembelajaran itu harus dapat dilakukan di sembarang tempat dan setiap saat. Saat ini pembelajaran dengan memanfaatkan mobile media sedang dikembangkan lebih luas. Tujuannya agar dapat semakin memudahkan proses pembelajaran siswa baik di sekolah maupun dimanapun mereka berada dan dalam kondisi apapun yang sedang dihadapinya. Sifat mobile media yang praktis dan hanya menggunakan sambungan koneksi saja untuk memperoleh sembarang macam informasi membuat peralatan mobile media mudah digunakan dimanapun tempatnya. Perangkat mobile media juga dapat memberikan bantuan untuk memperluas pengetahuan atau menggali informasi-informasi secara online. Adanya mobile media juga dapat menghubungkan seseorang dengan orang lain yang jauh jaraknya. Oleh karena itu, banyak manfaat positif dengan adanya perangkat mobile media.

Pengembangan kamus bahasa Jawa digital yang secara khusus ditujukan untuk siswa sekolah dapat menjadi salah satu sarana untuk melengkapi kebutuhan siswa tentang sumber belajar bahasa Jawa yang lebih bersifat interaktif dan selaras dengan perkembangan zaman. Kamus bahasa Jawa digital yang dikembangkan dalam penelitian ini dibuat dengan menggunakan aplikasi android. Meier (2012, p.1) menjelaskan bahwa android adalah sebuah paltform pertama yang bersifat terbuka dan komprehensif untuk peralatan mobile. Android bisa dijalankan dalam smartphone, tablet, komputer, serta perangkat bergerak lainnya. Kelebihan android yang lain yaitu multitasking, mudah memunculkan noti- 


\section{LingTera,6 (1), 2019 - 20}

\section{Nur Hanifah Insani, Mulyana Mulyana}

fikasi, aksesnya yang mudah untuk ribuan jenis aplikasi android dengan Google Android App Market, pilihan jenis ponsel yang beraneka ragam, bisa menginstal ROM yang sudah dimodifikasi, adanya widget, serta google maniak (Safaat, 2012, pp.5-6). Semua kelebihan android tersebut tentu saja dapat membuat para siswa setuju jika ada suatu media pembelajaran bahasa Jawa yang dibuat dengan menggunakan software android.

Tujuan penelitian ini untuk mengembangkan media pembelajaran kamus bahasa Jawa digital dengan aplikasi android, mengetahui kualitas serta kelayakan media pembelajaran tersebut. Media pembelajaran kamus bahasa Jawa digital dengan aplikasi android dibuat dengan tujuan agar menjadi salah satu media pembelajaran bahasa Jawa yang bersifat mobile learning sehingga dapat memudahkan peserta didik untuk mempelajari bahasa Jawa dimanapun dan kapan pun juga. Pada akhirnya, pengetahuan siswa tentang kosakatan bahasa Jawa dapat meningkat lebih banyak agar proses pembelajaran bahasa Jawa dapat berjalan dengan lancar.

\section{METODE}

Penelitian ini termasuk penelitian dan pengembangan atau Research and Development (R\&D) yang bertujuan untuk menghasilkan produk pembelajaran yang dapat digunakan sesuai kebutuhan. Gall, Borg, \& Gall (2007) mengatakan bahwa penelitian pengembangan adalah sebuah proses untuk mengembangkan dan memvalidasi produk-produk yang digunakan dalam pendidikan. Produk pengembangan di bidang pendidikan yang dihasilkan dalam penelitian ini berupa kamus bahasa Jawa digital berbasis android yang telah melalui proses validasi dan evaluasi produk.

Model pengembangan yang digunakan dalam penelitian ini yaitu model yang diadaptasi dari model Borg \& Gall (1983, p.776-788) dengan dikelompokkan menjadi tiga tahap sebagai berikut: (1) studi pendahuluan, pada tahap ini kegiatan yang dilakukan adalah melakukan studi pustaka, studi pembelajaran bahasa Jawa di lapangan sebagai bagian dari penelitian pra survei, serta mendeskripsikan dan menganalisis hasil penelitian, (2) pengembangan produk, pada tahap ini pengembang menganalisis kebutuhan dan karakteristik siswa, menganalisis kurikulum untuk menetapkan kompetensi hasil belajar, pengembangan produk yang meliputi pembuatan storyboard, menentukan sarana prasarana yang akan digunakan termasuk mengembangkan alat evaluasi, menentukan tahap-tahap uji desain di lapangan, serta validasi ahli, dan (3) evaluasi (ujicoba) produk, pada tahap ini ujicoba lapangan dilakukan sebanyak dua tahap yakni tahap ujicoba terbatas dengan melibatkan 12 peserta didik serta tahap ujicoba lapangan yang lebih luas dengan melibatkan 60 peserta didik.

Produk media divalidasi oleh ahli media dan ahli materi. Penilaian media juga dilakukan oleh pendidik bahasa Jawa. Hasil dari penilaian dan komentar tersebut digunakan untuk perbaikan media. Media selanjutnya diujicobakan secara terbatas pada peserta didik dan hasil sekaligus komentar dari peserta didik digunakan untuk perbaikan media. Media selanjutnya diujicobakan dalam skala lapangan yang lebih luas. Hasil uji coba lapangan yang lebih luas digunakan untuk perbaikan media hingga didapatkan produk akhir media pembelajaran bahasa Jawa berupa kamus bahasa Jawa digital berbasis android.

Pengumpulan data pada penelitian ini menggunakan angket. Data penilaian media diperoleh dengan menggunakan angket penilaian oleh ahli media, ahli materi, pendidik bahasa Jawa, dan peserta didik. Data yang diperoleh melalui uji coba diklasifikasikan menjadi dua, yaitu data kuantitatif dan data kualitatif. Data kualitatif berupa komentar dan saran yang dikemukakan oleh ahli media, ahli materi, pendidik bahasa Jawa, serta peserta didik dikumpulkan sebagai bahan pertimbangan untuk memperbaiki produk media pembelajaran. Data kuantitatif berupa skor digunakan untuk mengetahui kualitas dan tingkat kelayakan produk media pembelajaran yang dihasilkan.

Teknik analisis data yang digunakan untuk mengetahui kualitas dan kelayakan produk multimedia pembelajaran yakni teknik deskriptif kuantitatif dengan menggunakan skala Likert. Data hasil penelitian berupa tanggapan ahli media, ahli materi, pendidik bahasa Jawa dan peserta didik tentang kualitas produk yang dikembangkan dari aspek pembelajaran, aspek ketepatan isi, aspek tampilan, serta aspek pemrograman. Data berupa komentar, saran revisi, dan hasil pengamatan selama proses uji coba dianalisis secara deskriptif kualitatif dan disimpulkan sebagai masukan untuk memperbaiki produk. Data berupa skor tanggapan ahli media, ahli materi, pendidik bahasa Jawa, dan siswa yang diperoleh dari kuesioner dianalisis secara deskriptif kuantitatif. Langkah-langkah yang dilakukan untuk menganalisis data, pertama, hasil review dari ahli materi, ahli media, 
pendidik bahasa Jawa, dan peserta didik dikonversikan dalam bentuk angka seperti Tabel 1 .

Tabel 1. Kategori Nilai Siswa

\begin{tabular}{lc}
\hline \multicolumn{1}{c}{ Kategori } & Nilai \\
\hline SS (Sangat Setuju) & 4 \\
S (Setuju) & 3 \\
TS (Tidak Setuju) & 2 \\
STS (Sangat Tidak Setuju) & 1 \\
\hline
\end{tabular}

Tabel 2. Kategori Nilai dari Ahli Materi, Ahli

Media, dan Pendidik Bahasa Jawa

\begin{tabular}{lc}
\hline \multicolumn{1}{c}{ Kategori } & Nilai \\
\hline BS (Baik Sekali) & 4 \\
B (Baik) & 3 \\
KB (Kurang Baik) & 2 \\
SKB (Sangat Kurang Baik) & 1 \\
\hline
\end{tabular}

Dari aspek yang direview, kemudian dicari rata-rata empirisnya dengan rumus Persamaan 1. $\bar{x}=\frac{\sum x}{N}$

Berdasarkan Rumus Persamaan 1, $\bar{x}$ adalah skor rata-rata, $\sum x$ merupakan jumlah skor, dan $n$ adalah jumlah subjek uji coba. Untuk mengetahui kualitas produk multimedia pembelajaran, data masing-masing variabel dikategorikan menjadi 4 kelas. Keempat kategori tersebut adalah (1) sangat baik, (2) baik, (3) tidak baik, dan (4) sangat tidak baik. Dasar penentuan keempat kategori tersebut menurut Lukman \& Ishartiwi (2014, p.112), adalah jika X empiris seperti pada Tabel 3.

Tabel 3. Kategori Penilaian Kualitas Produk oleh Ahli Materi, Ahli Media, dan Pendidik Bahasa Jawa

\begin{tabular}{ccl}
\hline Nilai & Skor & \multicolumn{1}{c}{ Kriteria } \\
\hline 4 & $x \geq M i+1,5 S D i$ & Sangat Baik \\
3 & $M i+1,5 S D i>x \geq M i$ & Baik \\
2 & $M i>x \geq M i-1,5 S D i$ & Kurang Baik \\
1 & $x \leq M i-1,5 S D i$ & Sangat Kurang \\
& & Baik \\
\hline
\end{tabular}

\section{HASIL DAN PEMBAHASAN}

\section{Studi Pendahuluan}

Tata cara penelitian yang dilakukan dalam penelitian ini diadaptasi dari model penelitan Borg \& Gall. Dari sepuluh urutan penelitan milik Borg \& Gall, dalam penelitan ini dibatasi hanya sampai pada urutan ketujuh setelah disesuaikan dengan ruang lingkup dan keterbatasan penelitian ini. Ketujuh langkah penelitian yang diambil lalu dikelompokkan menjadi tiga tahap, yaitu tahap studi pendahuluan, tahap pengembangan produk, dan tahap uji lapangan. Tahap studi pendahuluan dibagi menjadi dua tahap, yakni tahap studi pustaka dan tahap pra-penelitian.

Berdasarkan hasil studi pustaka dapat diketahui bahwa proses pembelajaran yang menggunakan media pembelajaran dapat menambah motivasi siswa untuk lebih memperhatikan materi pelajaran yang disampaikan guru di kelas. Respon yang positif ini tentu saja di kemudian hari dapat meningkatkan prestasi belajar siswa. Kondisi seperti ini juga didukung dari hasil penelitian-penelitian yang telah dilakukan sebelumnya bahwa teknologi pembelajaran dapat membantu terwujudnya tujuan pembelajaran yang telah ditentukan. Selain itu, kamus bahasa Jawa juga sangat lah penting keberadaannya untuk membantu siswa meningkatkan pengetahuan tentang kosakata bahasa Jawa.

Berdasarkan hasil studi pra-survey di lapangan ditemukan kondisi bahwa proses pembelajaran bahasa Jawa masih berlangsung secara konvensional. Hal ini terbukti dari metode pembelajaran yang digunakan oleh guru ketika mengajar di kelas yang masih menggunakan metode ceramah. Peserta didik hanya diminta mendengarkan materi pelajaran di kelas, sedangkan guru dengan asyiknya mencatatkan materi di papan tulis lalu menerangkannya kepada peserta didik. Alhasil, proses pembelajaran masih bersifat teacher centered, belum students centered. Sarana prasarana yang disediakan sekolah sebenarnya cukup memadai dengan adanya LCD, proyektor, wifi, serta sebagian besar peserta didik yan sudah memiliki handphone atau gadget dengan fitur-fitur aplikasi yang terkini. Sayangnya, semua fasilitas atau sarana prasarana yang ada belum dapat dimanfaatkan dengan maksimal sebagai suatu media pembelajran oleh para guru bahasa Jawa. oleh karena itu, perlu kiranya membuat suatu media pembelajaran dengan memanfaatkan sarana prasarana yang sudah disediakan oleh sekolah dengan cuma-cuma.

\section{Pengembangan Produk Media Pembelajaran}

Pembuatan produk media pembelajaran kamus bahasa Jawa digital berbasis aplikasi android dengan menggunakan software Android Studio sebagai software utama pengembangan produk. Selain itu, produk media pembelajaran juga dikembangkan menggunakan SQLite, suatu software yang berfungsi sebagai database, dalam hal ini akan menjadi database kamus bahasa Jawa digital ini serta software CorelDraw X7 untuk membuat desain tampilan produk. Produk media pembelajaran dalam penelitian ini dibuat dnegan menggunakan hardware dengan spesifikasi hard 
disk 500GB, RAM 8 GB, serta dengan sistem operasi Windows 8.1. Seluruh komponen yang telah disiapkan untuk membuat produk lalu dijadikan satu menggunakan software Android Studio. Komponen-komponen produk lalu dirangkai menjadi satu agar dapat menyatu sesuai dengan rancangan yang telah dibuat pada flowchart dan storyboard penelitian.

Gambaran komponen/fitur-fitur yang terdapat pada media pembelajaran kamus bahasa Jawa digital dengan android adalah sebagai berikut. Pertama, akan muncul bagian loading screen yang juga sekaligus berperan sebagai welcome screen. Bagian ini akan memunculkan nama aplikasi produk yang dibuat. Kedua, menu utama (homepage) yang memuat lima (5) menu utama dan empat (4) menu tambahan. Keempat menu utama tersebut adalah menu pados tembung (cari kata), bausastra (kamus), terjemahan, latihan soal, serta petunjuk. Menu Pados Tembung atau Cari Kata digunakan untuk mencari kata secara cepat dengan lebih fokus/sempit ruang lingkup bahasanya, yakni dalam bahasa Jawa ragam ngoko atau krama, serta bahasa Indonesia. Menu Bausastra atau Kamus ini memuat semua entri data yang terdapat dalam kamus. Dalam menu ini pengguna dapat melihat secara keseluruhan entri kata yang ada. Di dalam menu Terjemahan, pengguna dapat menerjemahkan entri kata yang dicari dari bahasa ngoko ke krama, bahasa ngoko ke Indonesia, ragam krama ke ngoko, ragam krama ke Indonesia, maupun dari bahasa Indonesia ke bahasa Jawa ragam ngoko serta krama. Menu latihan soal memuat pertanyaan-pertanyaan untuk melatih ingatan siswa tentang kosakata bahasa Jawa yang telah dipelajari. Soal yang dibuat dalam aplikasi ini juga telah disesuaikan dengan materi-materi pelajaran bahasa Jawa siswa SMA/SMK kelas X, XI, serta XII. Menu Petunjuk memuat enam (6) sub menu, yakni sub menu bahasa untuk memilih jenis bahasa yang akan dipakai untuk menggunakan aplikasi, apakah akan menggunakan bahasa Jawa atau bahasa Indonesia; sub menu keterangan menu yang menjelaskan fungsi menumenu yang terdapat di dalam aplikasi, petunjuk penggunaan aplikasi, tentang media, saran, profil, serta versi media. Semua sub menu dapat dibaca dalam dua bahasa, yakni bahasa Jawa dan bahasa Indonesia.

Menu tambahan dibuat sebagai menu penguat keterangan materi. Di dalam menu tambahan terdapat empat menu, yakni menu kompetensi materi, target penguasaan kata, daftar singkatan, serta daftar pustaka. Menu Kompe- tensi Materi memuat struktur Kurikulum Tingkat Satuan Pendidikan (KTSP) serta Kurikulum 2013 SMA/SMK sederajat kelas X, XI, dan XII di Provinsi Jawa Tengah. Menu Target Penguasaan Materi memuat target penguasaan kosakata yang harus dikuasai oleh siswa setelah selesai mempelajari setiap tema materi pelajaran bahasa Jawa. Jumlah kata yang harus dikuasai setiap tema berbeda tergantung kerumitan materi yang disampaikan. Menu Daftar Singkatan memuat beraneka ragam singkatan yang terdapat di dalam penyusunan kamus. Menu Daftar Singkatan ini terbagi menjadi dua sub menu, yaitu sub menu daftar singkatan serta sub menu penanda. Menu daftar pustaka memuat referensi penyusunan kamus bahasa Jawa digital berbasis android yang beraneka ragam asalnya.

\section{Penilaian Produk Media Pembelajaran}

Penilaian produk media pembelajaran kamus bahasa Jawa digital berbasis android oleh ahli materi dilakukan oleh seorang dosen bahasa Jawa yang memiliki keahlian di bidang materi tata bahasa. Penilaian produk oleh ahli materi tentang aspek pembelajaran dan aspek kebenaran isi. Ahli materi memberikan saran untuk perbaikan media kamus bahasa Jawa digital berbasi android tentang isi aplikasi yang seharusnya memuat: (1) target penguasaan materi bagi siswa setiap tema; (2) tes atau latihan soal untuk mengetahui peningkatan kosakata siswa dan pemahaman penguasaan materi; serta (3) materi kamus hendaknya disesuaikan dengan tema setiap jurusan-jurusan yang ada di Sekolah Menengah Kejuruan (SMK).

Penilaian produk media pembelajaran oleh ahli media dilakukan oleh dosen ahli media pembelajaran bahasa Jawa. Penilaian produk oleh ahli media dari aspek tampilan media serta aspek pemrograman. Ahli media memberikan saran perbaikan produk kamus bahasa Jawa digital berbasis android tentang: (1) pembuatan soal didasarkan materi buku agat terdapat content validity; (2) cek kata-kata yang tidak ada maknanya atau salah tulis; (3) diberi audio suara pengucapan entri kata.

Penilaian produk media pembelajaran kamus bahasa Jawa digital berbasis android oleh guru bahasa Jawa dilakukan di tempat dan waktu yang berbeda-beda. Penilaian produk media pembelajaran pada tahap uji coba lapangan terbatas dilakukan oleh dua (2) orang pendidik bahasa Jawa, yakni guru SMK Muhammadiyah 2 Salam dan guru SMK Muhammadiyah 1 Muntilan. Saran yang diberikan oleh para pendidik bahasa 
Jawa berdasarkan hasil uji coba terbatas, yaitu (1) penulisan nama aplikasi seharusnya menggunakan huruf kapital; dan (2) Background tampilan dibuat yang lebih menarik.

Penilaian produk oleh pendidik bahasa Jawa pada tahap uji coba lapangan yang lebih luas dilakukan oleh enam (6) guru bahasa Jawa. Keenam pendidik bahasa Jawa tersebut terdiri dari 1 guru SMK Muhammadiyah 2 Salam, 2 guru SMK Muhammadiyah 1 Salam, 1 guru SMK Muhammadiyah 1 Muntilan, 1 guru SMK Negeri 1 Salam, serta 1 guru dari SMA Negeri 1 Muntilan. Hasil pendapat dari guru bahasa Jawa tentang produk media pembelajaran kamus bahasa Jawa digital pada tahap uji coba lapangan yang lebih luas adalah sebagai berikut: (1) diteliti lagi penggunaan contoh kalimat berbahasa Indonesia agar lebih tepat struktur kalimatnya; (2) akan lebih baik lagi jika aplikasi kamus bahasa Jawa digital dapat dibuka dan dijalankan menggunakan komputer/laptop; serta (3) produk kamus bahasa Jawa digital berbasi android yang telah dibuat disebarluaskan kepada seluruh pendidik bahasa Jawa SMA/SMK se Kabupaten Magelang.

Para siswa juga memberikan pendapatnya terhadap produk kamus bahasa Jawa digital berbasis android, yaitu sebagai berikut; (1) aplikasi kamus bahasa Jawa digital dapat di-install di handphone tetapi tidak kuat untuk dijalankan programnya, (2) aplikasi tidak daapt diinstall, (3) jumlah kosakata kurang banyak; dan (4) tampilan media dibuat yang lebih menarik.

\section{Hasil Validasi Ahli Materi}

Penilaian produk media pembelajaran oleh ahli materi terdiri atas 13 indikator yang terbagi dalam dua aspek, yaitu aspek pemeblajaran dan aspek kebenaran isi. Aspek pembelajaran memuat 7 indikator. Pada tahap validasi yang pertama, 3 indikator mendapat nilai 4.00 (sangat baik) dan 4 indikator mendapat bilai 3 (baik). Jumlah nilai keseluruhan adalah 24.00 sehingga dapat dikategorikan kedalam kategori sangat baik dari sisi kualitas materi pembelajarannya. Skor rata-ratanya sebesar 3,43 dengan persentase sebesar $85,71 \%$ sehingga kelayakan materi pelajaran termasuk kategori sangat layak. Pada tahap validasi kedua, 6 indikator mendapat nilai 4.00 (sangat baik) dan 1 indikator mendapat nilai 3.00 (baik). Jumlah nilai akhirnya adalah 27.00 sehingga termasuk kategori sangat baik dari segi kualitasnya. Skor rata-rata pada tahap kedua ini yaitu 3,86 dengan persentase sebesar 96,43\% sehingga kelayakan materi pembelajaran termasuk kategori sangat layak.

Aspek kebenaran isi memuat enam (6) indikator. Pada tahap validasi yang pertama, 4 indikator mendapat nilai 4.00 (sangat baik) dan 2 indikator mendapat nilai 3.00 (baik). Jumlah nilainya adalah 20.00 sehingga termasuk kategori sangat baik dari penilaian kualitas produknya. Skor rata-rata penilaian produk pada tahap ini yaitu 3,33 dengan persentase $83,33 \%$ sehingga kelayakan media dari aspek kebenaran isi materi pelajaran termasuk kategori sangat layak. Pada tahap validasi kedua, 4 indikator mendapat nilai 4.00 (sangat baik) dan 2 indikator mendapat nilai 3.00 (baik). Jumlah nilainya yaitu 22.00 sehingga termasuk kategori sangat baik dari sisi penilaian kualitas kebenaran isi materi pelajaran. Skor ratarata penilaian kedua yaitu 3,67 dengan persentase sebesar $91.67 \%$ sehingga kelayakan kebenaran isi pelajaran juga termasuk kategori sangat layak.

Dari kedua aspek yang telah dinilai, keduanya mendapat persentase kelayakan media yang termasuk kategori sangat layak. Kategori ini menunjukkan bahwa multimedia kamus bahasa Jawa digital berbasis android layak digunakan sebagai bahan uji coba lapangan setelah dilakukan revisi produk sesuai dengan saran ahli materi. Tabel 4 dan Tabel 5 merupakan ringkasan penilaian kua-litas dan kelayakan media oleh ahli materi.

Tabel 4. Rekapitulasi Hasil Penilaian Kualitas Produk oleh Ahli Materi

\begin{tabular}{lclcl}
\hline \multirow{2}{*}{ Aspek } & \multicolumn{2}{c}{ Tahap I } & \multicolumn{2}{c}{ Tahap II } \\
\cline { 2 - 5 } & Jumlah & Kategori & Jumlah & Kategori \\
\hline Pembelajaran & 24.00 & Sangat & 27.00 & Sangat \\
& & Baik & & Baik \\
Kebenaran isi & 20.00 & Sangat & 22.00 & Sangat \\
& & Baik & & Baik \\
Total & 44.00 & Sangat & 49.00 & Sangat \\
& & Baik & & Baik \\
\hline
\end{tabular}

Tabel 5. Rekapitulasi Hasil Penilaian Kelayakan Produk oleh Ahli Materi

\begin{tabular}{lcccc}
\hline \multirow{2}{*}{ Aspek } & \multicolumn{2}{c}{ Tahap I } & \multicolumn{2}{c}{ Tahap II } \\
\cline { 2 - 5 } & $\%$ & Kategori & $\%$ & Kategori \\
\hline Pembelajaran & $85,71 \%$ & Sangat & $96,43 \%$ & Sangat \\
& & Layak & & Layak \\
Kebenaran isi & $83,33 \%$ & $\begin{array}{c}\text { Sangat } \\
\text { Layak }\end{array}$ & $91,67 \%$ & Sangat \\
Rerata & $84,62 \%$ & $\begin{array}{c}\text { Layat } \\
\text { Sangat } \\
\text { Layak }\end{array}$ & $94,23 \%$ & Layak \\
& Sangat & Layak \\
\hline
\end{tabular}

Hasil Validasi Ahli Media

Penilaian produk media pembelajaran oleh ahli media terdiri atas limabelas (15) indikator 


\section{LingTera, 6 (1), 2019 - 24}

Nur Hanifah Insani, Mulyana Mulyana

yang terbagi dalam dua (2) aspek, yakni aspek tampilan media serta aspek pemrograman. Aspek tampilan terdiri atas delapan (8) indikator. Pada tahap validasi pertama, 3 indikator mendapat nilai 4.00 (sangat baik) dan 5 indikator mendapat nilai 3.00 (baik). Jumlah nilainya 27.00 sehingga kualitas media pembelajaran termasuk kategori sangat baik. Skor rata-rata pada tahap ini yaitu 3,38 dengan persentase sebesar 84,38\% sehingga tampilan media termasuk kategori sangat layak. Pada tahap validasi kedua, 6 indikator mendapat nilai 4.00 (sangat baik) dan 2 indikator mendapat nilai 3.00 (baik). Jumlah nilai akhirnya 30,00 sehingga kualitas media termasuk kategori sangat baik. Skor rata-rata akhir adalah 3,75 dengan persentase sebesar $93,75 \%$ sehingga kelayakan tampilan media pembelajaran kamus bahasa Jawa digital berbasis android termasuk kategori sangat layak digunakan.

Tabel 6. Rekapitulasi Hasil Penilaian Kualitas Produk oleh Ahli Media

\begin{tabular}{lclcl}
\hline \multirow{2}{*}{ Aspek } & \multicolumn{2}{c}{ Tahap I } & \multicolumn{2}{c}{ Tahap II } \\
\cline { 2 - 5 } & Jumlah & Kategori & Jumlah & Kategori \\
\hline Tampilan & 27.00 & Sangat & 30.00 & Sangat \\
& & Baik & & Baik \\
Pemrograman & 25.00 & Sangat & 26.00 & Sangat \\
& & Baik & & Baik \\
Total & 52.00 & $\begin{array}{l}\text { Sangat } \\
\text { San }\end{array}$ & 56.00 & Sangat \\
& & & Baik & Baik \\
\hline
\end{tabular}

Tabel 7. Rekapitulasi Hasil Penilaian Kelayakan Produk oleh Ahli Media

\begin{tabular}{|c|c|c|c|c|}
\hline \multirow{2}{*}{ Aspek } & \multicolumn{2}{|c|}{ Tahap I } & \multicolumn{2}{|c|}{ Tahap II } \\
\hline & $\%$ & Kategori & $\%$ & Kategori \\
\hline Tampilan & $84,38 \%$ & $\begin{array}{l}\text { Sangat } \\
\text { Layak }\end{array}$ & $93,75 \%$ & $\begin{array}{l}\text { Sangat } \\
\text { Layak }\end{array}$ \\
\hline Pemrograman & $89,29 \%$ & $\begin{array}{l}\text { Sangat } \\
\text { Layak }\end{array}$ & $92,86 \%$ & $\begin{array}{l}\text { Sangat } \\
\text { Layak }\end{array}$ \\
\hline Rerata & $86,67 \%$ & $\begin{array}{l}\text { Sangat } \\
\text { Layak }\end{array}$ & $93,33 \%$ & $\begin{array}{l}\text { Sangat } \\
\text { Layak }\end{array}$ \\
\hline
\end{tabular}

Aspek pemrograman terdiri atas tujuh (7) indikator. Pada tahap validasi pertama, 4 indikator mendapat nilai 4.00 (sangat baik) dan 3 indikator (baik). Jumlah nilainya 25,00 sehingga kualitas pemrograman media termasuk kategori sangat baik. Skor rata-rata penilaian pada tahap ini adalah 3,57 dengan persentase sebesar 89,29\% sehingga kelayakan pemrograman media termasuk kategori sangat layak. Pada tahap validasi kedua, 5 indikator medapat nilai 4.00 (sangat baik) dan 2 indikator mendapat nilai 3.00 (baik). Jumlah nilai akhirnya adalah 26,00 sehingga kualitas pemrogarman media masih termasuk kategori sangat baik. Skor rata-rata penilaian tahap kedua oleh ahli media yaitu 3,71 dengan persentase sebesar 92,86\% sehingga kelayakan pemrograman media termasuk kategori sangat layak.

Dari kedua aspek yang telah dinilai oleh ahli media, keduanya mendapat persentase kelayakan media dengan kategori sangat layak. Kategori ini menunjukkan bahwa multimedia kamus bahasa Jawa digital berbasis android layak digunakan sebagai bahan uju coba lapangan setelah dilakukan revisi produk berdasarkan masukan dari ahli media. Tabel 6 dan Tabel 7 merupakan ringkasan penilaian kualitas dan kelayakan media oleh ahli media.

\section{Hasil Uji Coba Terbatas}

Uji coba lapangan terbatas dilakukan oleh dua (2) pendidik bahasa Jawa dan duabelas (12) peserta didik. Penilaian produk media pembelajaran oleh pendidik bahasa Jawa terdiri atas 25 indikator yang terbagi dalam empat (4) aspek penilaian, yakni aspek pembelajaran, aspek kebenaran isi, aspek tampilan, serta aspek pemrograman. Aspek pembelajaran terdiri atas 7 indikator. Guru bahasa Jawa yang pertama memberikan nilai 4.00 (sangat baik) untuk 4 indikator dan nilai 3.00 (baik) untuk 3 indikator. Jumlah nilainya yaitu 25,00 sehingga kualitas media termasuk kategori sangat baik. Skor rata-rata yang didapat yaitu 3,57 dengan persentase kelayakan media sebesar $89,29 \%$ sehingga termasuk kategori sangat layak. Guru bahasa Jawa yang kedua memberikan nilai 4.00 (sangat baik) untuk 6 indikator dan nilai 3.00 (baik) untuk 1 indikator. Jumlah nilainya yaitu 27,00 sehingga termasuk kategori sangat baik. Skor rata-rata yang didapat yaitu 3,86 dengan persentase kelayakan media sebesar 96,43\% sehingga termasuk kategori sangat layak digunakan sebagai media pembelajaran.

Aspek kebenaran isi terdiri atas 6 indikator. Guru bahasa Jawa yang pertama memberikan nilai 4.00 (sangat baik) untuk 2 indikator dan nilai 3.00 (baik) untuk 4 indikator. Jumlah nilainya yaitu 20,00 sehingga kualitas media termasuk kategori sangat baik. Skor rata-rata yang didapat yaitu 3,33 dengan persentase kelayakan media sebesar $83,33 \%$ sehingga termasuk kategori sangat layak. Guru bahasa Jawa yang kedua memberikan nilai 3.00 (baik) untuk 6 indikator. Jumlah nilainya yaitu 18,00 sehingga termasuk kategori sangat baik. Skor rata-rata yang didapat yaitu 3,00 dengan persentase kelayakan media sebesar $75,00 \%$ sehingga termasuk kategori layak digunakan sebagai media pembelajaran. 
Aspek tampilan media terdiri dari 8 indikator. Guru bahasa Jawa yang pertama memberikan nilai 4.00 (sangat baik) untuk 4 indikator dan nilai 3.00 (baik) untuk 4 indikator. Jumlah nilainya yaitu 28,00 sehingga kualitas media termasuk kategori sangat baik. Skor rata-rata yang didapat yaitu 3,5 dengan persentase kelayakan media sebesar $87,50 \%$ sehingga termasuk kategori sangat layak. Guru bahasa Jawa yang kedua memberikan nilai 4.00 (sangat baik) untuk 3 indikator dan nilai 3.00 (baik) untuk 5 indikator. Jumlah nilainya yaitu 27,00 sehingga termasuk kategori sangat baik. Skor rata-rata yang didapat yaitu 3,37 dengan persentase kelayakan media sebesar 84,38\% sehingga termasuk kategori sangat layak digunakan.

Aspek pemrograman terdiri atas 3 indikator. Guru bahasa Jawa yang pertama memberikan nilai 4.00 (sangat baik) untuk 3 indikator. Jumlah nilainya yaitu 12,00 sehingga kualitas media termasuk kategori sangat baik. Skor rata-rata yang didapat yaitu 4,00 dengan persentase kelayakan media sebesar 100,00\% sehingga termasuk kategori sangat layak. Guru bahasa Jawa yang kedua memberikan nilai 4.00 (sangat baik) untuk 1 indikator dan nilai 3.00 (baik) untuk 2 indikator. Jumlah nilainya yaitu 10,00 sehingga termasuk kategori sangat baik. Skor rata-rata yang didapat yaitu 3,33 dengan persentase kelayakan media sebesar 83,33\% sehingga termasuk kategori sangat layak digunakan.

Dari keempat aspek yang telah dinilai, keseluruhan aspek mendapat persentase kelayakan media dengan kategori sangat layak. Kategori ini menunjukkan bahwa multimedia kamus bahasa Jawa digital berbasis android layak digunakan sebagai salah satu media pembelajaran bahasa Jawa di kelas. Tabel 8 dan Tabel 9 merupakan hasil pendapat guru bahasa Jawa terhadap produk media pembelajaran kamus bahasa Jawa digital berbasis android.

Ada empat aspek yang dinilai oleh siswa pada tahap uji coba terbatas, yaitu aspek kebermanfaatan kamus, aspek kemandirian siswa, aspek penyajian media, dan aspek pengoperasian media. Hasil pendapat dua belas (12) siswa terhadap 20 indikator penilaian produk media pembelajaran mendapat persetujuan siswa yang termasuk dalam kategori sangat setuju. Aspek kebermanfaatan kamus mendapat jumlah nilai 157 dengan skor rata-rata 13,08 dan hasil persentase sebesar $81,77 \%$ sehingga termasuk dalam kategori sangat setuju. Aspek kemandirian siswa juga mendapat jumlah nilai 157 dengan skor ratarata 13,08 dan hasil persentase sebesar $81,77 \%$. Hasil perhitungan tersebut dapat dikategorikan dalam kategori sangat setuju. Aspek penyajian media mendapat jumlah nilai 184 dengan skor rata-rata 15,33 dan persentase sebesar $76,67 \%$ sehingga termasuk kategori sangat setuju. Jumlah nilai pada aspek pengoperasian media yaitu 274 dengan skor rata-rata 22,83 dan persentase sebesar $81,55 \%$ sehingga termasuk dalam kategori sangat setuju. Hasil rekapitulasi pendapat siswa terhadap produk media pembelajaran kamus bahasa Jawa digital berbasis android pada tahap uji coba lapangan terbatas dapat dilihat pada Tabel 10 .

Tabel 8. Rekapitulasi Hasil Pendapat Guru Bahasa Jawa terhadap Kualitas Produk Media Pembelajaran

\begin{tabular}{lcccc}
\hline \multirow{2}{*}{ Aspek } & \multicolumn{3}{c}{ Guru I } & \multicolumn{2}{c}{ Guru II } \\
\cline { 2 - 5 } & Jumlah & Kategori & Jumlah & Kategori \\
\hline Pembelajaran & 25.00 & Sangat Baik & 27.00 & Sangat Baik \\
Kebenaran Isi & 20.00 & Sangat Baik & 18.00 & Sangat Baik \\
Tampilan & 28.00 & Sangat Baik & 27.00 & Sangat Baik \\
Pemrograman & 12.00 & Sangat Baik & 10.00 & Sangat Baik \\
Total & 85.00 & Sangat Baik & 82.00 & Sangat Baik \\
\hline
\end{tabular}

Tabel 9. Rekapitulasi Hasil Pendapat Guru Bahasa Jawa terhadap Kelayakan Produk Media Pembelajaran

\begin{tabular}{|c|c|c|c|c|}
\hline \multirow{2}{*}{ Aspek } & \multicolumn{2}{|c|}{ Tahap I } & \multicolumn{2}{|c|}{ Tahap II } \\
\hline & $\%$ & Kategori & $\%$ & Kategori \\
\hline Pembelajaran & $89,29 \%$ & Sangat Layak & $96,43 \%$ & Sangat Layak \\
\hline Kebenaran Isi & $83,33 \%$ & Sangat Layak & $75,00 \%$ & Layak \\
\hline Tampilan & $87,50 \%$ & Sangat Layak & $84,38 \%$ & Sangat Layak \\
\hline Pemrograman & $100,00 \%$ & Sangat Layak & $83,33 \%$ & Sangat Layak \\
\hline Rerata & $85,00 \%$ & Sangat Layak & $82,00 \%$ & Sangat Layak \\
\hline
\end{tabular}


LingTera, 6 (1), 2019 - 26

Nur Hanifah Insani, Mulyana Mulyana

Tabel 10. Rekapitulasi Hasil Pendapat Siswa pada Tahap Uji Coba Terbatas

\begin{tabular}{lcccc}
\hline \multicolumn{1}{c}{ Aspek } & Jumlah & Rata-rata & $\%$ & Kategori \\
\hline Kebermanfaatan kamus & 157 & 13,08 & $81,77 \%$ & Sangat Setuju \\
Kemandirian siswa & 157 & 13,08 & $81,77 \%$ & Sangat Setuju \\
Penyajian media & 184 & 15,33 & $76,67 \%$ & Sangat Setuju \\
Pengoperasian media & 274 & 22,83 & $81,55 \%$ & Sangat Setuju \\
\multicolumn{1}{c}{ Total } & 772 & 64,33 & $80,42 \%$ & Sangat Setuju \\
\hline
\end{tabular}

Tabel 11. Rekapitulasi Hasil Pendapat Guru pada Tahap Uji Coba Lapangan yang Lebih Luas

\begin{tabular}{lcccc}
\hline \multicolumn{1}{c}{ Aspek } & Jumlah & Rata-rata & $\%$ & Kategori \\
\hline Pembelajaran & 157 & 26,17 & $93,45 \%$ & Sangat Baik \\
Kebenaran Isi & 130 & 21,67 & $90,28 \%$ & Sangat Baik \\
Tampilan & 175 & 29,17 & $91,15 \%$ & Sangat Baik \\
Pemrograman & 68 & 11,33 & $94,44 \%$ & Sangat Baik \\
\multicolumn{1}{c}{ Total } & 530 & 88,33 & $92,01 \%$ & Sangat Baik \\
\hline
\end{tabular}

Tabel 12. Rekapitulasi Hasil Pendapat Siswa pada Tahap Uji Coba Lapangan yang Lebih Luas

\begin{tabular}{lccc}
\hline \multicolumn{1}{c}{ Aspek } & Rata-rata & $\%$ & Kategori \\
\hline Kebermanfaatan kamus & 14,43 & $90,21 \%$ & Sangat Setuju \\
Kemandirian siswa & 14,60 & $91,25 \%$ & Sangat Setuju \\
Penyajian media & 16,67 & $83,33 \%$ & Sangat Setuju \\
Pengoperasian media & 23,72 & $84,70 \%$ & Sangat Setuju \\
\multicolumn{1}{c}{ Total } & 69,42 & $86,77 \%$ & Sangat Setuju \\
\hline
\end{tabular}

Hasil Uji Coba Lapangan yang Lebih Luas

Uji coba lapangan yang lebih luas dilakukan oleh enam (6) orang guru bahasa Jawa dan 60 peserta didik. Penilaian produk media pembelajaran oleh guru bahasa Jawa terdiri dari 25 indikator yang terbagi atas empat aspek penilaian, yakni aspek pembelajaran, aspek kebenaran isi, aspek tampilan media, serta aspek pemrograman. Hasil pendapat guru bahasa Jawa terhadap produk media pembelajaran kamus bahasa Jawa digital berbasis android dilihat dari skor akhir penilaian yang telah dilakukan. Hasilnya, kualitas produk media pembelajaran termasuk dalam kategori sangat baik dan tingkat kelayakan media pembelajaran dari setiap aspek juga termasuk kategori sangat layak.

Aspek pembelajaran mendapat jumlah nilai 157 dengan skor rata-rata 26,17 sehingga termasuk dalam kategori sangat baik. Hasil perhitungan kelayakan media dalam persentase sebesar $93,45 \%$ sehingga termasuk dalam kategori sangat layak. Aspek kebenaran isi materi pembelajaran mendapat jumlah nilai 130 dengan skor rata-rata 21,67 sehingga termasuk dalam kategori sangat baik. Hasil perhitungan kelayakan media dalam persentase sebesar 90,28\% sehingga termasuk dalam kategori sangat layak.Jumlah nilai aspek tampilan media adalah 175 dengan skor rata-rata 29,17 sehingga termasuk dalam kategori sangat baik. Hasil perhitungan kelayakan media dalam persentase sebesar $91,15 \%$ sehingga ter- masuk dalam kategori sangat layak. Aspek pemrograman mendapat akumulasi skor sebesar 68 dengan skor rata-rata 11,33 sehingga termasuk dalam kategori sangat baik. Hasil perhitungan kelayakan media dalam persentase sebesar 94,44\% sehingga termasuk dalam kategori sangat layak.

Dari keempat aspek penilaian media yang ada, kualitas produk media pembelajaran dari setiap aspeknya termasuk kategori sangat baik. Kategori yang demikian menunjukkan bahwa multimedia kamus bahasa Jawa digital berbasis android sudah dianggap memiliki kualitas yang sangat baik sebagai salah satu media pembelajaran bahasa Jawa. Hasil perhitungan kelayakan produk media pembelajaran juga termasuk kategori sangat layak digunakan sebagai suatu media pembelajaran bahasa Jawa. Tingkat kelayakan media pembelajaran juga dapat disebut sangat layak karena isi materi yang terdapat pada produk media pembelajaran kamus bahasa jawa digital dapat digunakan untuk membantu kelancaran proses pembelajaran bahasa Jawa di kelas. Tabel 11 merupakan ringkasan hasil pendapat guru bahasa Jawa terhadap produk kamus bahasa Jawa digital berbasis android.

Ada empat aspek yang dinilai oleh siswa pada tahap uji coba lapangan yang lebih luas, yaitu aspek kebermanfaatan kamus, aspek kemandirian siswa, aspek penyajian media, serta aspek pengoperasian media. Hasil pendapat enam puluh (60) siswa terhadap 20 indikator persetuju- 
an siswa atas produk media pembelajaran kamus bahasa Jawa bahwa rata-rata para siswa sangat setuju dengan setiap butir pernyataan yang telah dituliskan. Keempat aspek penilaian media pembelajaran mendapat persetujuan siswa dalam kategori sangat setuju.

Aspek kebermanfaatan kamus mendapat skor rata-rata persetujuan siswa yang besarnya 14,43 dengan perhitungan persentase sebesar 90,21\% sehingga dapat dikelompokkan dalam kategori sangat setuju. Skor rata-rata persetujuan siswa dalam aspek kemandirian siswa yaitu sebesar 14,60 dengan hasil persentase sebesar 91,25\% sehingga termasuk dalam kategori sangat setuju. Skor rata-rata persetujuan siswa dalam aspek penyajian media sebesar 16,67 dengan kisaran persentase sebesar $83,33 \%$ sehingga masuk dalam kategori sangat setuju. Aspek pengoperasian media mendapat rata-rata persetujuan siswa sebesar 23,72 dengan persentase sebesar 84,70\% sehingga termasuk dalam kategori sangat setuju. Hasil rekapitulasi pendapat siswa terhadap produk media pembelajaran kamus bahasa Jawa digital berbasis android pada tahap uji coba lapangan yang lebih luas dapat dilihat pada Tabel 12.

Hasil pendapat siswa yang demikian menunjukkan bahwa para siswa sudah sangat setuju dengan adanya produk media pembelajaran kamus bahasa Jawa digital berbasis android. Hal ini dikarenakan kamus bahasa Jawa digital berbasis android ini sudah dapat dikategorikan sebagai suatu media pembelajaran yang memiliki kualitas sangat baik dan sesuai dengan kriteria media pembelajaran yang baik. Adanya aplikasi kamus bahasa Jawa digital berbasis android ini tentu saja akan menyenangkan para siswa karena wujudnya yang ringkas sehingga rasa malas untuk membaca kamus cetak yang tebal bisa hilang. Para siswa juga sudah menyatakan persetujuannya akan adanya revisi produk media pembelajaran kamus bahasa Jawa digital berbasis android yang lebih baik lagi dari aplikasi yang telah dibuat sebelumnya.

\section{SIMPULAN}

Pertama, hasil penelitian pengembangan ini berupa aplikasi media pembelajaran kamus bahasa Jawa digital berbasis android. Karakteristik produk yang dihasilkan memuat menu utama dan menu tambahan. Ada lima (5) menu utama (homepage) dan empat (4) menu tambahan dalam aplikasi tersebut. Keempat menu utama tersebut adalah menu pados tembung (cari kata), menu bausastra (kamus), menu terjemahan, menu latihan soal, serta menu petunjuk. Sedangkan menu tambahan yang berfungsi sebagai menu untuk penjelas keterangan materi meliputi menu kompetensi materi, menu target penguasaan kosakata, menu daftar singkatan, serta menu daftar pustaka. Evaluasi yang berupa soal-soal dibuat dalam wujud pilihan ganda dan dibuat dalam wujud games Quiz Parampa.

Kedua, kelayakan aplikasi kamus bahasa Jawa digital berbasis android untuk siswa SMA/ SMK berdasarkan penilaian validator media dan validator materi termasuk dalam kategori sangat layak. Kualitas produk media pembelajaran pada penilaian tahap validasi terakhir oleh dosen ahli materi mendapat skor 49,00 sehingga termasuk dalam kategori sangat baik. Kelayakan media pembelajaran berdasarkan hasil penilaian dosen ahli materi mendapat persentase sebesar 94,23\% sehingga termasuk dalam kategori sangat baik. Hasil penilaian kualitas produk oleh dosen ahli media pada tahap validasi yang terakhir mendapat skor 56,00 sehingga termasuk kategori sangat baik. Kelayakan media pembelajaran oleh ahli media medapat persentase sebesar $93,33 \%$ sehingga termasuk kategori sangat layak. Kategori kelayakan media pembelajaran yang seluruhnya termasuk kategori sangat layak menunjukkan bahwa media pembelajaran kamus bahasa Jawa digital berbasis android sangat layak digunakan sebagai bahan produk uji coba lapangan yang nantinya diharapkan dapat menjadi salah satu media pembelajaran yang dapat bermanfaat bagi peserta didik untuk mempelajari bahasa Jawa.

Ketiga, penilaian guru bahasa Jawa terhadap produk kamus bahasa Jawa digital berbasis android pada tahap uji coba terbatas mendapat rata-rata persentase $86,98 \%$, sedangkan pada tahap uji coba lapangan yang lebih luas mendapat rata-rata persentase $92,01 \%$ sehingga persentase keduanya termasuk dalam kategori sangat baik. Hasil persetujuan siswa terhadap produk media pembelajaran kamus bahasa Jawa digital berbasis android mendapat rata-rata persentase $80,07 \%$ pada tahap uji coba terbatas dan mendapat persentase $84,70 \%$ pada tahap uji coba lapangan yang lebih luas. Persentase yang demikian termasuk dalam kategori persetujuan sangat setuju. Kategori sangat setuju ini menunjukkan bahwa guru bahasa Jawa serta para perserta didik beranggapan bahwa media pembelajaran kamus bahasa Jawa digital berbasis android tersebut sudah dibuat dengan sangat baik sehingga dapat menarik perhatian para peserta didik untuk belajar bahasa Jawa utamanya untuk memperluas pengetahuan kosakata bahasa Jawa. 


\section{LingTera, 6 (1), 2019 - 28}

Nur Hanifah Insani, Mulyana Mulyana

\section{DAFTAR PUSTAKA}

Agustien, R., Umamah, N., \& Sumarno, S. (2018). Pengembangan media pembelajaran video animasi dua dimensi situs Pekauman di Bondowoso dengan model ADDIE mata pelajaran Sejarah kelas X IPS. Jurnal Edukasi, 5(1), 19 - 23. doi:10.19184/jukasi.v5i1.8010

Annisah, S. (2017). Alat peraga pembelajaran matematika. Tarbawiyah Jurnal Ilmiah Pendidikan, 11(01), 1-15. Retrieved from http://e-

journal.metrouniv.ac.id/index.php/tarbawi yah/article/view/356

Arafik, M., \& Rumidjan, R. (2017). Profil pembelajaran unggah-ungguh bahasa Jawa di sekolah dasar. Sekolah Dasar: Kajian Teori dan Praktik Pendidikan, 25(1), 5561.

doi:http://dx.doi.org/10.17977/um009v25i 12016p055

Azmi, N., Maryono, D., \& Rosihan, A. Y. (2016). Android based application for supporting English for disability. Proceeding of the International Conference on Teacher Training and Education, 2(1), pp. 194201.

Borg, W. R., \& Gall, M. D. (1984). Educational research: An introduction. Longman Publishing

Gall, M. D., Borg, W. R., \& Gall, J. P. (2007). Educational research: An introduction. Longman Publishing.

Georgiev, T., Georgieva, E., \& Smrikarov, A. (2004). M-learning-a New Stage of ELearning. International Conference on Computer Systems and TechnologiesCompSysTech, 4(28), pp. 1-4.

Collins, A., \& Halverson, R. (2018). Rethinking education in the age of technology: The digital revolution and schooling in America. Teachers College Press.

Darmawan, D. (2012). Teknologi Pembelajaran. Bandung: PT Remaja Rosdakarya.

Irwandani, I., \& Juariyah, S. (2016). Pengembangan media pembelajaran berupa komik fisika berbantuan sosial media instagram sebagai alternatif pembelajaran. Jurnal Ilmiah Pendidikan Fisika Al-Biruni, 5(1), 33-42. doi:https://doi.org/10.24042/jpifalbiruni.v 5i1.103
Kustandi, C., \& Sutjipto, B. (2011). Media pembelajaran manual dan digital. Bogor: Ghalia Indonesia.

Latuheru, J.D. (1988). Media pembelajaran dalam proses belajar mengajar masa kini. Jakarta: Departemen Pendidikan dan Kebudayaan Direktorat Jenderal Pendidikan Tinggi Proyek Pembinaan Tenaga Kependidikan.

Levie, W. H., \& Lentz, R. (1982). Effects of text illustrations: A review of research. Ectj, $30(4)$,

$195-$ 232.doi:https://doi.org/10.1007/BF027651 84

Lukman, L., \& Ishartiwi, I. (2014). Pengembangan bahan ajar dengan model mind map untuk pembelajaran ilmu pengetahuan sosial SMP. Jurnal Inovasi Teknologi Pendidikan, 1(2), 109-122. doi:https://doi.org/10.21831/tp.v1i2.2523

Meier, R. (2012). Professional android 4 application development. John Wiley \& Sons.

Kartikasari, G. (2016). Pengaruh media pembelajaran berbasis multimedia terhadap motivasi dan hasil belajar materi sistem pencernaan manusia: Studi eksperimen pada siswa kelas V MI Miftahul Huda Pandantoyo. Jurnal Dinamika Penelitian: Media Komunikasi Penelitian Sosial Keagamaan, 16(1), 5977. doi:10.21274/dinamika.2016.16.1.5977

Purbasari, R. J., Kahfi, M. S., \& Yunus, M. (2013). Pengembangan aplikasi android sebagai media pembelajaran matematika pada materi dimensi tiga untuk siswa SMA kelas X. Jurnal Online Universitas Negeri Malang, 1(4), 1-10.

Ramadhani, T., Koryati, D., \& Deskoni, D. (2015). Analisis model dan media pembelajaran yang digunakan oleh guru pada mata pelajaran ekonomi di SMA seKecamatan Inderalaya. Jurnal PROFIT Kajian Pendidikan Ekonomi dan Ilmu Ekonomi, 2(1), 34-45. Retrived from https://ejournal.unsri.ac.id/index.php/jp/ar ticle/view/5532

Safaat, N. (2012). Pemrograman aplikasi mobile smartphone dan tablet PC berbasis android. Bandung: Informatika.

Usman, M. B., \& Asnawir, H. (2002). Media pembelajaran. Ciputat Pers. 
LingTera,6 (1), 2019 - 29

Nur Hanifah Insani, Mulyana Mulyana

Widoyoko, E. P. (2012). Teknik penyusunan instrumen penelitian. Yogyakarta: Pustaka Pelajar.

Yulianti, T., Herkulana, H., \& Achmadi, A. (2018). Pengaruh penggunaan media pembelajaran terhadap hasil belajar siswa pada mata pelajaran ekonomi di SMA. Jurnal Pendidikan dan Pembelajaran, 7(1). Retrived from http://jurnal.untan.ac.id/index.php/jpdpb/a rticle/view/23511
Silviarista, M., \& Setyosari, P. (2018). Pengembangan multimedia pembelajaran berbasis mobile untuk mata pelajaran bahasa Jawa materi aksara Jawa kelas VIII SMP. JINOTEP (Jurnal Inovasi dan Teknologi Pembelajaran) Kajian dan Riset dalam Teknologi Pembelajaran, 4(1), 2227. Retrived from http://journal2.um.ac.id/index.php/jinotep/ article/view/2389 